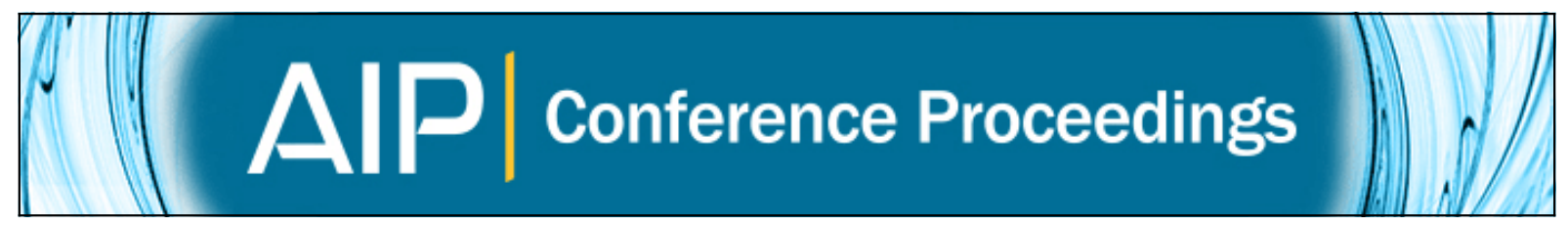

\title{
Structural transitions in alumina nanoparticles by heat treatment
}

Nirmal Kaur, Atul Khanna, Banghao Chen, and Fernando González

Citation: AIP Conference Proceedings 1731, 030027 (2016); doi: 10.1063/1.4947632

View online: http://dx.doi.org/10.1063/1.4947632

View Table of Contents: http://scitation.aip.org/content/aip/proceeding/aipcp/1731?ver=pdfcov

Published by the AIP Publishing

\section{Articles you may be interested in}

Improvement and protection of niobium surface superconductivity by atomic layer deposition and heat treatment Appl. Phys. Lett. 93, 192504 (2008); 10.1063/1.2995996

Mechanism of enhancement/deterioration of boiling heat transfer using stable nanoparticle suspensions over vertical tubes

J. Appl. Phys. 102, 074317 (2007); 10.1063/1.2794731

Effects of nanoparticle deposition on surface wettability influencing boiling heat transfer in nanofluids Appl. Phys. Lett. 89, 153107 (2006); 10.1063/1.2360892

Effect of nanoparticles on critical heat flux of water in pool boiling heat transfer Appl. Phys. Lett. 83, 3374 (2003); 10.1063/1.1619206

Uniform deposition of ultrathin polymer films on the surfaces of Al 2 O 3 nanoparticles by a plasma treatment Appl. Phys. Lett. 78, 1243 (2001); 10.1063/1.1352700 


\title{
Structural Transitions in Alumina Nanoparticles by Heat Treatment
}

\author{
Nirmal Kaur ${ }^{1}$, Atul Khanna ${ }^{1 *}$, Banghao Chen ${ }^{2}$ and Fernando González ${ }^{3}$ \\ ${ }^{I}$ Glass Physics and Sensors Laboratory, Department of Physics, \\ Guru Nanak Dev University, Amritsar-143005, Punjab, India. \\ ${ }^{2}$ Department of Chemistry \& Biochemistry, Florida State University, \\ Tallahassee, FL 32306-4390, USA. \\ ${ }^{3}$ Department of Chemistry and Process \& Recourse Engineering, \\ University of Cantabria, Santander-39005, Spain. \\ *Email: atul.phy@gndu.ac.in
}

\begin{abstract}
C}, 950^{\circ} \mathrm{C}$ and $1100^{\circ} \mathrm{C}$ and structural transitions as a function of heat treatment were studied by X-ray diffraction (XRD), Differential Scanning Calorimetry (DSC) and ${ }^{27} \mathrm{Al}$ Magic Angle Spinning Nuclear Magnetic Resonance (MAS-NMR) methods.. XRD studies found that $\gamma-\mathrm{Al}_{2} \mathrm{O}_{3}$ is stable upto a temperature of at least $950^{\circ} \mathrm{C}$ and transforms to the thermodynamically stable $\alpha$-phase after annealing at $1100^{\circ} \mathrm{C}$. MAS-NMR revealed that $\gamma$-alumina contains $\mathrm{AlO}_{4}$ and $\mathrm{AlO}_{6}$ structural units in the ratio 1: 2, while $\alpha$-phase contains only $\mathrm{AlO}_{6}$ units. DSC confirmed that $\gamma \rightarrow \alpha$ transition initiates at $1060^{\circ} \mathrm{C}$.
\end{abstract}

Keywords: Alumina nanoparticles, XRD, DSC, MAS-NMR.

PACS: 61.46.Df, 61.05.cp, 65.60.+a, 76.60.-k

\section{INTRODUCTION}

Aluminum oxide commonly known as alumina $\left(\mathrm{Al}_{2} \mathrm{O}_{3}\right)$, is one of the most interesting ceramic materials both for its numerous applications and excellent physical properties [1]. Alumina exists in a several metastable polymorphs, the so-called transition alumina (such as $\gamma, \delta, \theta, \chi$ and $\kappa$ ) as well as its thermodynamically stable $\alpha-\mathrm{Al}_{2} \mathrm{O}_{3}$ phase [2].

The metastable alumina polymorphs show structural transitions upon heating, with transformation sequence irreversibly ending in the $\alpha$-phase at temperatures in the range of 1100 to $1200^{\circ} \mathrm{C}$. The $\alpha$ alumina transformation temperature is however, relatively high, and it is possible to form many of the metastable phases at synthesis conditions between room temperature and $1000{ }^{\circ} \mathrm{C}$ [3].

The metastable phases such as $\gamma$-alumina find use in numerous applications. The low surface energy and therefore the inherent high surface areas of $\gamma$-alumina have made it useful for catalysis applications. Furthermore, thin films of amorphous alumina have proved to be very useful as optical coatings and as a dielectric layers in microelectronics devices [4].
In this work, we report the study of phase transformations in $\gamma$-alumina nanoparticles. Nanoparticles were annealed at three temperatures and characterized by X-ray diffraction (XRD), Differential Scanning Calorimetry (DSC) and ${ }^{27}$ Al MAS-NMR.

\section{EXPERIMENTAL METHODS}

$\gamma$-alumina nanopowder (Aldrich Inc., 99.9\% particle size $<50 \mathrm{~nm}$ ) weighing $2 \mathrm{~g}$ was taken as a starting material. The powder was ground in an agate motor-pestle and subjected to heat treatment in the temperature range of $800-1100^{\circ} \mathrm{C}$. X-ray diffraction and ${ }^{27} \mathrm{Al}$ MAS-NMR were performed after each annealing treatment to study the phase transformation properties. The initial sample (labelled as $\gamma$-AluminaRT) was analysed by DSC to determine the temperature of structural transitions. Details of heat treatment of nanoparticles are given in Table 1.

$\mathrm{X}$-ray diffraction studies were performed on Bruker D8 Focus X-ray diffractometer with $\mathrm{Cu} \mathrm{K}_{\alpha}$ radiation $(\lambda$ $=1.54056 \AA$ ) in the $2 \theta$ range of $10^{\circ}-70^{\circ}$. Thermal studies were performed on the initial $\gamma-\mathrm{Al}_{2} \mathrm{O}_{3}$ sample on SETARAM SETSYS Evolution-1750 system in the temperature range of $200-1500^{\circ} \mathrm{C}$ at a heating rate of $10^{\circ} \mathrm{C} \mathrm{m}^{-1}$ and airflow rate of $20 \mathrm{ml} \mathrm{m}^{-1}$ in Pt pans. ${ }^{27} \mathrm{Al}$ 
MAS-NMR spectra were collected with a $3.2 \mathrm{~mm}$ Varian MAS probe at room temperature on a Varian NMR spectrometer operating at $16.4 \mathrm{~T}$ corresponding to the Larmor frequency of $182.42 \mathrm{MHz}$ for ${ }^{27} \mathrm{Al}$ nuclei. Chemical shifts was referenced to $1 \mathrm{M}$ $\mathrm{Al}\left(\mathrm{NO}_{3}\right)_{3}(\mathrm{aq})$.

\section{RESULTS AND DISCUSSION}

Figure 1 shows XRD patterns of alumina nanoparticles annealed upto a maximum temperature of $1100^{\circ} \mathrm{C}$.

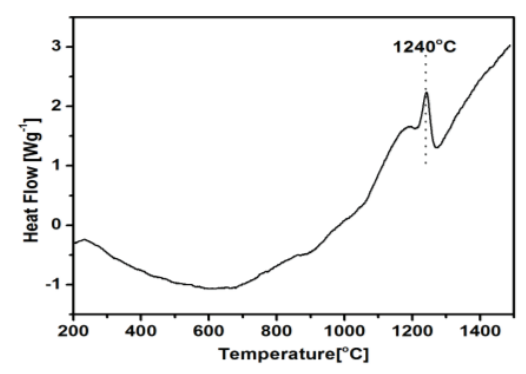

FIGURE 2. DSC thermogram of $\gamma-\mathrm{Al}_{2} \mathrm{O}_{3}$-RT sample.

TABLE 1: Details of annealing treatment of $\gamma-\mathrm{Al}_{2} \mathrm{O}_{3}$ powder and fraction of ${ }^{[4]} \mathrm{Al},{ }^{[5]} \mathrm{Al}$ and ${ }^{[6]} \mathrm{Al}$ species as measured by ${ }^{27} \mathrm{Al}$ MAS-NMR.

\begin{tabular}{ccccc}
\hline Sample Code & $\begin{array}{c}\text { Annealing Temperature } \\
{\left[{ }^{\mathbf{C}} \mathbf{C}\right]}\end{array}$ & ${ }^{\left[{ }^{4]} \mathbf{A l}\right.}$ & ${ }^{[5]} \mathbf{A l}$ & ${ }^{\left[{ }^{6]}\right.} \mathbf{A l}$ \\
\hline$\gamma$-Alumina-RT & - & 0.330 & 0.022 & 0.646 \\
$\gamma$-Alumina-800 & 800 & 0.343 & 0.020 & 0.635 \\
$\gamma$-Alumina-950 & 950 & 0.357 & 0.017 & 0.625 \\
$\gamma$-Alumina-1100 & 1100 & 0 & 0.022 & 0.978 \\
\hline
\end{tabular}

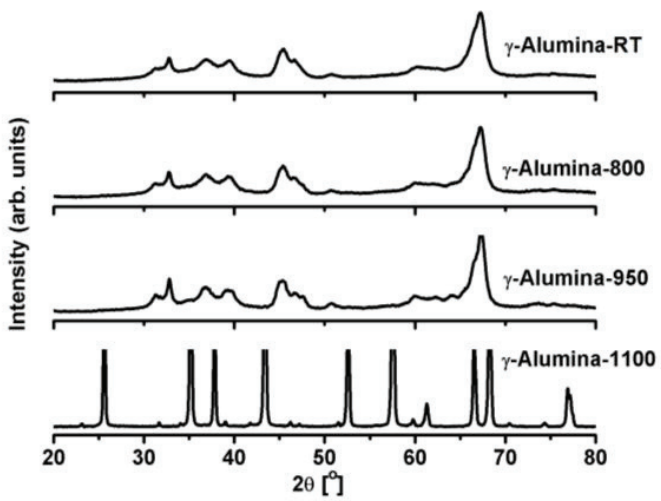

FIGURE 1. XRD patterns of initial $\gamma$-alumina powder (Sample Code: $\gamma$-Alumina-RT) and annealed samples.

XRD pattern of the initial $\mathrm{Al}_{2} \mathrm{O}_{3}$ powder $(\gamma-$ Alumina-RT) shows two prominent but broad peaks centered at $45.9^{\circ}$ and $67.1^{\circ}$ corresponding to $\gamma$-alumina [5]. XRD patterns of the samples annealed at $800^{\circ} \mathrm{C}$ and at $950^{\circ} \mathrm{C}$, do not show any significant changes and match with those of the initial $\gamma-\mathrm{Al}_{2} \mathrm{O}_{3}$ sample (Figure $1)$, whereas after annealing at $1100^{\circ} \mathrm{C}$, sharp peaks are detected due to its transformation to $\alpha-\mathrm{Al}_{2} \mathrm{O}_{3}$ [6]. Peak positions in the XRD patterns of all samples are presented in Table 2.

DSC studies confirm that transition of $\gamma$-alumina into $\alpha$-phase occurs at $1240^{\circ} \mathrm{C}$ with onset point of $1064^{\circ} \mathrm{C}$. Hence the transformation to $\alpha$-phase after heat treatment at $1100^{\circ} \mathrm{C}$ can be understood [Figure 2].
${ }^{27}$ Al MAS-NMR spectra are shown in Figure 3. The spectra consist of four peaks centered at $\sim 8,14,35$ and $70 \mathrm{ppm}$. Peaks at $\sim 8 \mathrm{ppm}$ and $\sim 14 \mathrm{ppm}$ are due to $\mathrm{AlO}_{6}$ structural units, $\mathrm{AlO}_{5}$ and $\mathrm{AlO}_{4}$ produce resonance peaks at $\sim 35$ and $70 \mathrm{ppm}$ respectively [7]. The initial sample ( $\gamma$-Alumina-RT) has two peaks at $\sim 8$ and $70 \mathrm{ppm}$ due to $\gamma$-phase, that is normally formed by thermal decomposition of aluminum oxy-hydroxide at $400^{\circ} \mathrm{C}$ [7]. The fractions of tetra, penta and hexa coordinated Al-O units are determined from the tatios of areas under the resonance peaks and their values are given in table 1 .

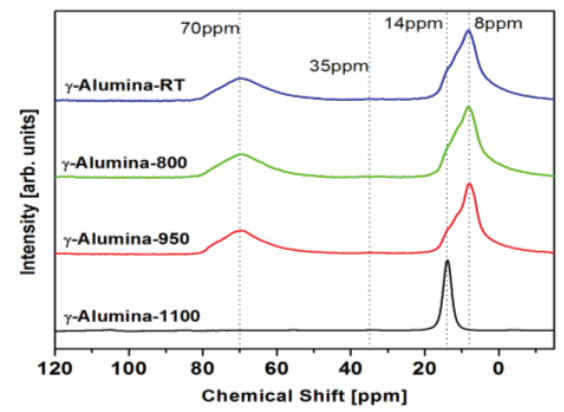

FIGURE 3. ${ }^{27} \mathrm{Al}$ MAS-NMR spectra of $\gamma$-alumina powder heat-treated upto $1100^{\circ} \mathrm{C}$. 
Table 2: XRD peak positions of $\gamma$-Alumina-RT and the sample annealed at $1100^{\circ} \mathrm{C}$. Corresponding crystalline

\begin{tabular}{ccc} 
phases are also listed & $\mathbf{\theta}\left[^{\mathbf{0}}\right]$ & $\begin{array}{c}\text { Crystalline } \\
\text { phases }\end{array}$ \\
\hline Sample no. & 32.7 & $\gamma$ \\
-Alumina-RT & 36.8 & $\gamma$ \\
& 39.5 & $\gamma$ \\
& 45.4 & $\gamma$ \\
$\gamma$-Alumina-1100 & 67.2 & $\gamma$ \\
& 84.6 & $\gamma$ \\
& 100.7 & $\alpha$ \\
& 25.6 & $\alpha$ \\
& 35.2 & $\alpha$ \\
& 37.8 & $\alpha$ \\
& 43.4 & $\alpha$ \\
& 52.6 & $\alpha$ \\
& 57.5 & $\alpha$ \\
& 61.3 & $\alpha$ \\
& 66.5 & $\alpha$ \\
& 68.2 & $\alpha$ \\
& 76.9 & $\alpha$ \\
\hline
\end{tabular}

From the data given in table 1 , it can be concluded that the initial $\gamma-\mathrm{Al}_{2} \mathrm{O}_{3}$ nanoparticles contain $33 \%$ of $\mathrm{AlO}_{4}$ units and $66 \%$ of six-coordinated, $\mathrm{AlO}_{6}$ units. On annealing $\gamma-\mathrm{Al}_{2} \mathrm{O}_{3}$ powder upto $950^{\circ} \mathrm{C}$, no significant changes take place in the concentration of short-range structural units. After annealing at $1100^{\circ} \mathrm{C}$, the sample contains $\sim 98 \%$ of $\mathrm{AlO}_{6}$ units. Hence, the initial $\gamma-\mathrm{Al}_{2} \mathrm{O}_{3}$ powder transforms almost completely to the rhombohedral $\alpha$-phase of $\mathrm{Al}_{2} \mathrm{O}_{3}$ with heat treatment at $1100^{\circ} \mathrm{C}$ for $6 \mathrm{~h}$.

\section{CONCLUSIONS}

$\gamma$-Alumina nanoparticles were heated in the temperature range of $800-1100^{\circ} \mathrm{C}$. Phase transitions after heat treatment at 800,950 and $1100^{\circ} \mathrm{C}$ are studied by XRD and ${ }^{27} \mathrm{Al}$ MAS-NMR. Sharp peaks in XRD pattern of the sample annealed at $1100^{\circ} \mathrm{C}$ confirm the transformation to the thermodynamically stable $\alpha$-phase. The fraction of $\mathrm{AlO}_{6}$ units is maximizes in this sample. The exothermic peak at $\sim 1240^{\circ} \mathrm{C}$ in the DSC thermogram is due to $\gamma \rightarrow \alpha$ transition.

\section{REFERENCES}

1. A. Boumaza, L. Favaro, J. Lédion, G. Sattonnay, J.B. Brubach, P. Berthet, A.M. Huntz, P. Roy and R. Tétot, Journal of Solid State Chemistry 182, 1171-1176 (2009).

2. S. Cava, S.M. Tebcherani, I.A. Souza, S.A Pianaro, C.A. Paskocimas, E. Longo and J.A. Varela, Materials Chemistry and Physics 103, 394399 (2007).
3. S. Kim, C. Kim and Y. Oh, Journal of Materials Science Letters 16, 257-259 (1997).

$4 . \quad$ L.D. Laude, K. Kolev, M. Brunel and P. Deleter, Applied Surface Science 86, 368-381 (1995).

5. PDF File \# 10-0425, ICDD: Newtown Street, PA, USA.

6. PDF File \# 10-0173, ICDD: Newtown Square, PA, USA.

7. L.A. O'Dell, S.L.P. Savin, A.V. Chadwick and M.E. Smith, Solid State Nuclear Magnetic Resonance 31, 169-173 (2007). 